\title{
Isolation and Characterization of Intestinal Stem Cells Based on Surface Marker Combinations and Colony-Formation Assay
}

\author{
FENGCHAO WANG ${ }^{1}$, DAVID SCOVILLE ${ }^{2}$, XI C. HE $^{1}$, MAXIME M. MAHE ${ }^{3}$, ANDREW BOX ${ }^{1}$, \\ JOHN M. PERRY ${ }^{1}$, NICHOLAS R. SMITH ${ }^{4}$, NAN YE LEI ${ }^{5}$, PAIGE S. DAVIES ${ }^{4}$, MEGAN K. \\ FULLER $^{3,6}$, JEFFREY S. HAUG ${ }^{1}$, MELAINIA MCCLAIN ${ }^{1}$, ADAM D. GRACZ ${ }^{6}$, SHENG DING ${ }^{7}$, \\ MATTHIAS STELZNER ${ }^{8,9}$, JAMES C. Y. DUNN ${ }^{9}$, SCOTT T. MAGNESS $^{6,10}$, MELISSA H. \\ WONG $^{4,10}$, MARTIN G. MARTIN ${ }^{5,10}$, MICHAEL HELMRATH ${ }^{3}$, and LINHENG LI ${ }^{1,2,10}$
}

${ }^{1}$ Stowers Institute for Medical Research, Kansas City, Missouri 2Department of Pathology, University of Kansas Medical Center, Kansas City, Kansas ${ }^{3}$ Cincinnati Children's Hospital Medical Research Center, Cincinnati, Ohio ${ }^{4}$ Department of Dermatology, Oregon Health \& Science University, Portland, Oregon ${ }^{5}$ Division of Gastroenterology, Department of Pediatrics, University of California, Los Angeles, Los Angeles, California ${ }^{6}$ Division of Gastroenterology and Hepatology, Cell Biology and Physiology, and Biomedical Engineering, Departments of Medicine and Surgery, University of North Carolina at Chapel Hill, Chapel Hill, North Carolina ${ }^{7}$ Gladstone Institute of Cardiovascular Disease, University of California, San Francisco, San Francisco, California ${ }^{8}$ Department of Surgery, VA Greater Los Angeles Healthcare System, Los Angeles, California ${ }^{9}$ Department of Surgery, University of California, Los Angeles, Los Angeles, California ${ }^{10}$ Intestinal Stem Cell Consortium, Duarte, California, Sponsored by the National Institute of Diabetes and Digestive and Kidney Diseases and the National Institute of Allergy and Infectious Diseases, Bethesda, Maryland

\section{Abstract}

BACKGROUND \& AIMS-Identification of intestinal stem cells (ISCs) has relied heavily on the use of transgenic reporters in mice, but this approach is limited by mosaic expression patterns and difficult to directly apply to human tissues. We sought to identify reliable surface markers of ISCs and establish a robust functional assay to characterize ISCs from mouse and human tissues.

METHODS-We used immunohistochemistry, real-time reverse-transcription polymerase chain reaction, and fluorescence-activated cell sorting (FACS) to analyze intestinal epithelial cells isolated from mouse and human intestinal tissues. We compared different combinations of surface markers among ISCs isolated based on expression of Lgr5-green fluorescent protein. We developed a culture protocol to facilitate the identification of functional ISCs from mice and then tested the assay with human intestinal crypts and putative ISCs.

RESULTS-CD $44^{+} \mathrm{CD} 24^{\mathrm{lo}} \mathrm{CD} 166^{+}$cells, isolated by FACS from mouse small intestine and colon, expressed high levels of stem cell-associated genes. Transit-amplifying cells and progenitor cells were then excluded based on expression of GRP78 or c-Kit. CD44 ${ }^{+} \mathrm{CD} 24^{\mathrm{lo}} \mathrm{CD} 166^{+}$

\section{(C) 2013 by the AGA Institute}

Reprint requests Address requests for reprints to: Linheng Li, PhD, Stowers Institute for Medical Research, 1000 East 50th Street, Kansas City, Missouri 64110. lil@stowers.org..

Supplementary Material Note: To access the supplementary material accompanying this article, visit the online version of Gastroenterology at www.gastrojournal.org, and at http://dx.doi.org/10.1053/j.gastro.2013.04.050.

Author names in bold designate shared co-first authorship.

Conflicts of interest The authors disclose no conflicts. 
GRP78 ${ }^{\text {lo/- }}$ putative stem cells from mouse small intestine included Lgr5-GFPhi and Lgr5GFPmed/lo cells. Incubation of these cells with the GSK inhibitor CHIR99021 and the E-cadherin stabilizer Thiazovivin resulted in colony formation by $25 \%$ to $30 \%$ of single-sorted ISCs.

CONCLUSIONS-We developed a culture protocol to identify putative ISCs from mouse and human tissues based on cell surface markers. $\mathrm{CD} 44^{+} \mathrm{CD} 24^{\mathrm{lo}} \mathrm{CD} 166^{+}, \mathrm{GRP} 78^{\mathrm{lo} /}$, and c-Kit ${ }^{-}$ facilitated identification of putative stem cells from the mouse small intestine and colon, respectively. CD $44^{+} \mathrm{CD} 24^{-/ l o} \mathrm{CD} 166^{+}$also identified putative human ISCs. These findings will facilitate functional studies of mouse and human ISCs.

\section{Keywords}

Stemness; Differentiation; Single-Cell Sorting; Flow Cytometry Analysis

The intestinal epithelium offers an elegant model for studying mammalian adult stem cells because of its simple structure and high turnover rate. In vivo genetic marking, coupled with lineage tracing, is a reliable approach for characterizing mouse intestinal stem cells (ISCs); however, this method depends on transgenic or knock-in animal models such as Lgr5-green fluorescent protein (GFP) to identify crypt base columnar (CBC) cells and reporter constructs for Bmi-1, mTert, Hopx, and Lrig 1 to mark +4 ISCs. ${ }^{1-6}$ In addition, these transgenic reporter mice often display mosaic expression; more importantly, their use in isolating these populations cannot be translated directly to human studies.

Several groups have reported sorting ISCs using single surface markers, including EphB2, CD24, and CD166. ${ }^{7-9}$ However, the common caveat is that a single surface marker is unable to effectively exclude progenitor and differentiated cells. For example, EphB2 is broadly expressed in $>60 \%$ of human crypt cells at variable levels, but even EphB ${ }^{\text {hi }}$ cells contain both ISCs and Muc2 ${ }^{+}$progenitor cells. ${ }^{7}$ The expression of Sox9-GFP or CD24 $4^{+}$was used to isolate ISCs but revealed only $0.2 \%$ to $0.6 \%$ colony-forming efficiency $(\mathrm{CFE})^{10}$; therefore, neither of these molecules alone can serve as a robust ISC biomarker.

Functional analysis is required to verify candidate markers for sorted ISCs. However, robust survival of ISCs using the reported in vitro culture method is dependent on Paneth cells (PCs). ${ }^{11,12}$ Although Wnt3a was reported to replace PCs in this in vitro culture system, ${ }^{12}$ there are controversial reports that single $\mathrm{Lgr}^{+} \mathrm{CBCs}$ can efficiently grow only when mixed with PCs, not with the addition of Wnt3a. ${ }^{13}$ Furthermore, the colon does not have PCs, and c-Kit ${ }^{+}$goblet cells may support the growth of colonic stem cells (CoSCs) but with very low efficiency. ${ }^{14}$ These data highlight the need to develop a robust in vitro culture method for ISC studies.

Currently, 2 subpopulations of ISCs have been reported to regulate tissue homeostasis: CBCs with rapidly cycling properties intermingled among PCs and quiescent ISCs located above the $\mathrm{PC}$ zone near the +4 position. ${ }^{1-3,15-17}$ Although CBCs were reported to also express all the +4 ISC markers, ${ }^{18}$ recent in vivo studies have shown that after genetic ablation or radiation damage, a reserve ISC population located above the $\mathrm{PC}$ zone is activated to regenerate the damaged epithelium. ${ }^{4,6,19,20}$ Despite this important finding, no surface markers are available to efficiently isolate either of the ISC populations.

In this study, we identified a combination of surface markers for isolating mouse ISCs with different Lgr5 expression levels, which were functionally characterized using a newly developed culture method. This method also improves culture of either human crypt or fluorescence-activated cell sorting (FACS)-isolated single human ISCs. 


\section{Materials and Methods}

\section{Mice and Human Tissues}

The Lgr5-enhanced GFP mouse model was provided by Hans Clevers. Adult mice (6-12 weeks old) were used in all experiments. All mice were housed in the animal facility at Stowers Institute for Medical Research and handled according to Stowers Institute for Medical Research and National Institutes of Health guidelines. All procedures were approved by the Institutional Animal Care and Use Committee of Stowers Institute for Medical Research. Use of human tissues was approved by the institutional review board at Cincinnati Children's Hospital Medical Research Center and by an institutional review board-exempt protocol at University of California, Los Angeles.

\section{Histological Analysis of Tissue}

Mouse intestinal tissue was fixed in $1 \times$ zinc formalin. The fixed tissues were embedded in paraffin and processed as previously described. ${ }^{21}$

\section{Mouse Intestinal Crypt Isolation and Cell Dissociation}

For information on mouse intestinal crypt isolation and cell dissociation, see Supplementary Materials and Methods.

\section{Cell Culture}

Sorted cells were collected at low temperature, pelleted, and embedded in Growth Factor Reduced Matrigel (BD Biosciences, San Jose, CA), followed by seeding on a prewarmed 96-well plate ( 200 to 300 single cells in 8.5-10 $\mu$ L Matrigel per well). Matrigel contained $750 \mathrm{ng} / \mathrm{mL}$ epidermal growth factor (Peprotech), $1.5 \mu \mathrm{g} / \mathrm{mL}$ Noggin (Peprotech, Rocky Hill, $\mathrm{NJ})$, and $15 \mu \mathrm{mol} / \mathrm{L}$ Jagged-1 (Anaspec, Fremont, CA). Prewarmed seeding media (100 $\mu \mathrm{L})$ was added after full polymerization of Matrigel. Seeding medium was Advanced Dulbecco's modified Eagle medium/F12, supplemented with penicillin $(100 \mathrm{U} / \mathrm{mL}) /$ streptomycin $(100$ $\mu \mathrm{g} / \mathrm{mL}$ ), Glutamax, $10 \mathrm{mmol} / \mathrm{L}$ HEPES, $1 \times \mathrm{N} 2,1 \times \mathrm{B} 27$ (all from Invitrogen, Carlsbad, CA), $1 \mathrm{mmol} / \mathrm{L} N$-acetylcysteine (Sigma St. Louis, MO), Thiazovivin $(2.5 \mu \mathrm{mol} / \mathrm{L}$; Sheng Ding Lab, San Francisco, CA), and CHIR99021 (2.5 $\mu \mathrm{mol} / \mathrm{L}$; Stemgent, Cambridge, MA). Growth factors containing $1 \mu \mathrm{g} / \mathrm{mL}$ R-Spondin 1 (R\&D Systems, Minneapolis, MN), 1 $\mu \mathrm{mol} / \mathrm{L}$ Jagged-1 peptide (Anaspec), $50 \mathrm{ng} / \mathrm{mL}$ epidermal growth factor (Invitrogen), and $100 \mathrm{ng} / \mathrm{mL}$ Noggin at final concentration were added on day 2 after cell seeding. ${ }^{11}$ The first media change was processed on day 4 by removing $50 \%$ and adding $50 \%$ freshly prepared Advanced Dulbecco's modified Eagle medium/F12, supplemented with penicillin/ streptomycin, Glutamax, HEPES, $2 \times$ N2, 2× B27, $2 \mu \mathrm{g} / \mathrm{mL}$ R-Spondin 1, $100 \mathrm{ng} / \mathrm{mL}$ epidermal growth factor, and $200 \mathrm{ng} / \mathrm{mL}$ Noggin. The culture was then maintained regularly by adding growth factors without Jagged-1 every other day and then changing the entire medium every 4 days. The same strategy was used for single colonic ISC culture. FGF4 (200 ng/mL; R\&D Systems) can be added during the first 8 days but is not essential for colony formation.

\section{Flow Cytometric Analysis}

Cells $\left(2-6 \times 10^{6} / \mathrm{mL}\right)$ were stained with antibodies (Supplementary Materials and Methods) for 30 minutes at $4^{\circ} \mathrm{C}$ followed by secondary antibody staining for another 30 minutes. After washing, cells were analyzed by MoFlo (DakoCytomation, Carpinteria, CA). Cell size gate, based on forward scatter and side scatter, was set up first to exclude cell debris and clumps; the other gates were set as shown in Figure 1. Flow cytometry data collection and cell sorting were performed with a MoFlo Legacy Cell Sorter (Beckman Coulter, Indianapolis, IN) (see details in Supplementary Materials and Methods). Postsort analysis of cells 
confirmed successful sorting of desired populations at high purity (Supplementary Figure 6). Data analysis was performed using FlowJo (Tree Star Inc, Ashland, OR).

\section{Measurement of CFE}

When seeding the sorted cells in Matrigel for culture, we fixed and stained 3 to 4 wells with 4',6-diamidino-2-phenylindole to count the initial number of seeding cells as the denominator. The average number of enteroids formed from the remaining 4 to 7 wells served as the numerator.

\section{Quantitative Reverse-Transcription Polymerase Chain Reaction}

TaqMan gene expression assays (Applied Biosystems, Foster City, CA) were performed on triplicate samples (Supplementary Materials and Methods). Data were normalized relative to 3 reference genes: $G U S B, T B P$, and $H p r t 1 .{ }^{22} \mathrm{Ct}$ values were calculated to obtain fold changes for sample comparison (DataAssist v3.0, Applied Biosystems, Foster City, CA).

\section{Statistical Analysis}

Data are represented as mean \pm SEM. Two-tailed Student $t$ test was used to determine statistical significance for bar charts or pairwise comparisons with a significance cutoff of $P$ $<.05$.

\section{Results}

\section{A Combination of Antibodies to CD44, CD24, and CD166 Purified Putative ISCs by Excluding Differentiated Cells From the Villus and Crypt}

We used a general strategy to enrich ISCs and to exclude differentiated cells with a combination of positive and negative markers, respectively (Figure $1 A$ ). Besides confirming a broad crypt-restricted CD44 expression (Figure $1 B$ ), we further found that CD44 expression was higher at the interface between 2 adjacent Lgr5-GFPhi $\mathrm{CBCs}$ than that between 2 adjacent PCs (Figure $1 C$ and Supplementary Figures 1 and 3). Furthermore, 2 additional ISC surface markers, CD24 and CD166 (ALCAM),${ }^{8-10}$ were highly expressed in the lower region of crypts where ISCs are located (Figure $1 D$ ). Together, these data suggest that CD44 can be used to select intestinal epithelial crypt cells, including ISCs, and that CD24 and CD166 can be further used to exclude transient-amplifying and some progenitor cells.

Using FACS, we performed sequential doublets via pulse-width gating, dead/apoptotic cells using 7-aminoactinomycin D plus annexin V, and blood cells with CD45 staining (Figure $1 E$ ). We also found that more than $97 \%$ of live $\mathrm{CD}^{-} 5^{-}$cells were $\mathrm{EpCAM}^{+}$cells, an epithelial cell marker, and thereby eliminated the need to incorporate EpCAM into our procedure (Supplementary Figure 2). After the purification of CD44+ crypt cells, we further applied CD24 and CD166 gating to cosegregate the cells into 4 subpopulations based on isotype staining (Figure $1 E$ and Supplementary Figure 1). To determine the cellular composition of these subpopulations, we then used reverse-transcription polymerase chain reaction (RT-PCR) to measure expression levels of stem cells and differentiation markers (Figure $1 F$ ) using the total unfractioned live intestinal epithelial cells (IECs) as the reference population.

Among these 4 groups (Figure $1 F$ ), the high expression of stem cell-associated genes in the $\mathrm{CD} 44^{+} \mathrm{CD} 24^{\text {lo }} \mathrm{CD} 166^{\text {med }}$ population and the low expression of differentiation genes in the $\mathrm{CD} 44^{+} \mathrm{CD} 24^{\mathrm{lo}} \mathrm{CD} 166^{\mathrm{lo}}$ population indicated the identification of putative ISCs with different Lgr5 expression levels in these 2 gates. The combination of CD166 and CD24 staining revealed a CD24 $4^{\mathrm{lo}}$ subpopulation with a more distinctive boundary compared with 
CD24 alone (Supplementary Figure 4). Thus, we combined CD $44^{+} \mathrm{CD} 24^{\mathrm{lo}} \mathrm{CD} 166^{\mathrm{lo}}$ and $\mathrm{CD} 44^{+} \mathrm{CD} 24^{\mathrm{lo}} \mathrm{CD} 166^{\text {med }}$ populations to define the $\mathrm{CD} 44^{+} \mathrm{CD} 24^{\mathrm{lo}} \mathrm{CD} 166^{+(\mathrm{lo}+\mathrm{med})}$ population that was used for further purifying ISCs.

The $\mathrm{CD} 44^{+} \mathrm{CD} 24^{-} \mathrm{CD} 166^{\text {lo }}$ population revealed the lowest expression of stem cell-related genes (Figure $1 F$, columns $1-3$ ). On the other hand, the $\mathrm{CD} 44^{+} \mathrm{CD} 24^{\mathrm{hi}} \mathrm{CD} 166^{+}$ subpopulation expressed a high level of secretory lineage markers but a low level of Ki67 expression (Figure 1F, columns 10-12), indicating that this population was enriched for secretory cells. Using immunostaining of Ki67, we confirmed the quantitative RT-PCR (qRT-PCR) results (Supplementary Figures 5 and 6). In addition, a previous study reported that a combination of side scatter and CD24 can separate CD24hi cells into 2 subpopulations that respectively select endocrine cells and PCs. ${ }^{12,13}$ Interestingly, the $\mathrm{CD} 24^{\mathrm{hi}} \mathrm{CD} 166^{\mathrm{hi}}$ cells derived from the $\mathrm{CD}_{4} 4^{-}$population also fell into the "PC" gate (Supplementary Figures 1 and 3), providing a potential method to analyze and sort heterogeneous secretory lineage cells.

\section{GRP78+ $^{+}$and GRP78-/lo Distinguished Progenitor Cells and Stem Cells, Respectively}

To further exclude remaining differentiated cells from the $\mathrm{CD} 44^{+} \mathrm{CD} 24^{\mathrm{lo}} \mathrm{CD} 166^{+}$ population, we tested other candidate surface markers, including the 78-kilodalton glucoseregulated protein (GRP78) (Figure 2A). ${ }^{23} \mathrm{We}$ found that GRP78 was expressed at the highest level in the villus (differentiated cell zone), at an intermediate level in the upper crypt (transient-amplifying cell zone), and at the lowest level in the lower crypt, thus negatively selecting for the majority of ISCs (Figure 2B). A combination of GRP78 and CD44 formed 3 subpopulations of cells defined as CD $44^{-} \mathrm{GRP} 78^{+}, \mathrm{CD} 44^{\mathrm{lo}} \mathrm{GRP} 78^{+}$, and CD44 ${ }^{\text {hi }}$ GRP78 ${ }^{-/ l o}$ (Figure $2 C$ ). qRT-PCR gene expression analysis showed that the $\mathrm{CD} 44^{\text {hi }} \mathrm{GRP} 78^{-/ \mathrm{lo}}$ and CD $44^{\mathrm{lo}} \mathrm{GRP} 78^{+}$populations, respectively, expressed the highest level and lowest level of ISC-related genes, indicating that the combination of GRP78 and CD44 can largely distinguish ISCs from progenitor cells (Figure $2 D$ ).

However, CD44 ${ }^{+} \mathrm{GRP} 78^{-/ \mathrm{lo}}$ could not efficiently exclude CD24 ${ }^{\text {hi }}$ differentiated cells (Supplementary Figure 7), so we combined GRP78 with the previously identified $\mathrm{CD} 44^{+} \mathrm{CD} 24^{10} \mathrm{CD} 166^{+}$population (Figure $2 E$ ). qRT-PCR assay showed that $\mathrm{CD} 44^{+} \mathrm{CD} 24^{\mathrm{lo}} \mathrm{CD} 166^{+} \mathrm{GRP} 78^{-/ / \mathrm{lo}}$ cells expressed higher levels (10-fold) of active ISCrelated genes ( $L g r 5$ and Ascl2) but lower levels of differentiation markers (ChgA, Alpi, and Muc2) than did CD $44^{+} \mathrm{CD} 24^{\circ} \mathrm{CD} 166^{+} \mathrm{GRP}^{+} 8^{+}$cells (Figure $2 F$ ). Taken together, these data indicate that inclusion of GRP7 $8^{-/ l o}$ expression facilitates further purifying ISCs from the $\mathrm{CD} 44^{+} \mathrm{CD} 24^{\mathrm{lo}} \mathrm{CD} 166^{+}$subpopulation. Interestingly, these 2 subpopulations express Lrig1 and Hopx, 2 reserve ISC-related genes, at similar levels, consistent with a recent report. ${ }^{18}$

\section{CD44 ${ }^{\text {hi }}$ CD24 ${ }^{\text {lo }} \mathrm{CD} 166^{+} \mathrm{C}-\mathrm{Kit}^{-}$Combinatorial Markers Identified Putative CoSCs}

To purify CoSCs, we applied a strategy similar to that used for ISCs (Figure $3 \mathrm{~A}$ ). CD44 immunostaining revealed a gradient expression in the colonic crypt, with the highest level in the putative CoSC zone of the crypt base ${ }^{1}$ (Figure $3 B$ ). Consistently, a clear separation of $\mathrm{CD} 44^{\text {hi }}, \mathrm{CD} 44^{\mathrm{med}}$, and $\mathrm{CD} 44^{-/ \mathrm{lo}}$ subpopulations could be attained by flow cytometry (Figure $3 C$ ). Similar to a reported ISC marker EphB2 2 hi 24 CD $44^{\text {hi }}$ can identify cells at the crypt base, including $\mathrm{Lgr}^{+}$stem cells, adjacent goblet cells, and Lgr5GFPlo cells (Figure $3 B$, arrows). Therefore, additional markers are required to exclude progenitor cells from CD44 ${ }^{\text {hi }}$ cells.

Immunostaining of colonic tissues showed that CD24hi cells localized mainly in the lower crypt, where they overlapped with some Muc2 ${ }^{+}$goblet cells (Figure $3 B$ ), whereas CD166 demonstrated a broader expression along the entire crypt axis (Figure $3 B$ ). With the addition 
of CD24 and CD166, the CD44hi population could be further separated into 3 subpopulations by flow cytometry: $\mathrm{CD} 24^{\mathrm{lo}} \mathrm{CD} 166^{\mathrm{lo}}, \mathrm{CD} 24^{\mathrm{lo}} \mathrm{CD} 166^{\mathrm{hi}}$, and CD24hi $\mathrm{CD} 166^{\text {med }}$ (Figure $3 C$ ). Compared with CD24hi $\mathrm{CD} 166^{\text {med }}$ cells, CD24 $4^{\text {lo }} \mathrm{CD} 166^{\mathrm{lo} / \mathrm{hi}}$ populations expressed a high level of stem cell-related genes and a low level of the goblet cell gene Muc2 (Figure 3E). We also found that EphB2 was expressed at similar levels in these populations (Figure $3 E$ ), indicating its inability to distinguish $\mathrm{CoSCs}$ from neighboring Muc2+ goblet cells.

Because we failed to detect GRP78 expression in the colon, we used c-Kit ${ }^{14}$ to negatively select Muc2 ${ }^{+}$cells (Figure $3 B$ ). Thus, $\mathrm{CD} 44^{\mathrm{hi}} \mathrm{CD} 24^{\mathrm{lo}} \mathrm{CD} 166^{+}$cells could be further divided into c- $\mathrm{Kit}^{+}$and c-Kit ${ }^{-}$populations by flow cytometry (Figure $3 C$ ). RT-PCR analysis revealed that $\mathrm{CD} 44^{\text {hi }} \mathrm{CD} 24^{\text {lo }} \mathrm{CD} 166^{+} \mathrm{c}-\mathrm{Kit}^{-}$cells expressed a 5 -fold higher level of $\mathrm{Lgr} 5$ and Ascl 2 and a much lower level of $M u c 2$ (Figure $3 F$ ). In addition, the combination of

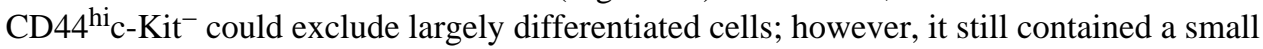
portion of CD24 ${ }^{\text {hi }}$ cells (recognizing secretory cells) (Supplementary Figure 8). Taken together, these data show that, although the combined markers $\mathrm{CD} 44^{\mathrm{hi}}{ }_{\mathrm{c}-\mathrm{Kit}^{-}}$can largely purify for CoSCs by FACS, a more pure population can be defined by $\mathrm{CD} 44^{\mathrm{hi}} \mathrm{CD} 24^{\mathrm{lo}} \mathrm{CD} 166^{+} \mathrm{cKit}{ }^{-}$.

\section{Inhibition of GSK3 $\beta$ and Stabilization of E-cadherin Enable Robust Colony Formation for Testing Single Stem Cells}

Characterizing single cells isolated using cell surface markers requires a robust functional assay. However, the current assay achieved only very low CFE even when supplementing the current medium with Wnt3a and other reported factors ${ }^{11}$ (Figure $4 A$ and Supplementary Figure 9). This is consistent with a recent report that Wnt3a cannot replace PCs to support efficient in vitro colony formation from single ISCs. ${ }^{13}$ We showed that Wnt3a conditional medium, containing myriad unknown factors, could only modestly increase the CFE of single ISCs (Supplementary Figure 10). However, a high frequency of cell death occurred during the first 4 days of culture, indicating that additional signaling pathways besides Wnt are essential for survival of ISCs.

CHIR99021, a GSK3 $\beta$ inhibitor, can efficiently activate $\beta$-catenin and potential other survival pathways. It has been effectively used for in vitro culture of embryonic ${ }^{25}$ and hematopoietic stem cells. ${ }^{26} \mathrm{We}$ found that only a low dose of CHIR99021 $(2.5 \mu \mathrm{mol} / \mathrm{L})$ during the first 2 days of culture (Figure $4 A$ ) enabled the survival of and subsequent robust growth of single Lgr5-GFPhi ISCs (Figure $4 C$ and Supplementary Figures 9 and 10), whereas a high dose (5-10 $\mu \mathrm{mol} / \mathrm{L})$ inhibited colony growth (Supplementary Figure 11).

Thiazovivin has been reported to increase the stability of E-cadherin and inhibit Rock activity, ${ }^{27}$ both of which are essential to reduce apoptosis and support survival of single cells during the first 2 days of culture. In our hands, Thiazovivin was more effective than the Rock inhibitor Y27632, as shown with either bigger colony sizes (Supplementary Figure 10) or higher CFE (see Materials and Methods for accurate measurement of CFE). With use of both CHIR99021 and Thiazovivin, we could increase the CFE of single Lgr5GFPhi ISCs up to $25 \%$ to $30 \%$ (Figure $4 A$ ).

We next used the same strategy for CoSC culture and observed formation of colonoids from single $\mathrm{CoSCs}^{28}$ (Figure $4 D$ ). We observed 2 types of colonoid structures during the growth of Lgr5GFPhi colonies: a closed form similar to enteroids and an open form with a typical colon-like polarized morphology (Figure $4 E$ ). We also observed that the closed form could transform into an open form as the colony grew (Supplementary Figure 12). These colonoids contained both $\mathrm{Lgr}^{-\mathrm{GFP}^{+}}$stem cells (Figure $4 E$ ) and differentiated cells, as revealed by electron microscopy analysis and immunostaining (Figure $4 F$ ). Taken together, our work 
supports the establishment of a robust culture system to evaluate stemness of sorted ISCs and CoSCs.

\section{Combinatorial Cell Surface Markers Show Purification of Functional ISCs and CoSCs}

Using the robust single-cell culture method, we measured the extent of ISC enrichment by our surface marker combination. We first used Lgr5-GFPhi ISCs as the reference to evaluate sorted cells for ISC identification. Given the mosaic expression of Lgr5-GFP, an increase in the percentage of Lgr5-GFPhi cells from $7.1 \%$ of the unfractioned live cells to $24.2 \%$ of the $\mathrm{CD} 44^{+} \mathrm{CD} 24^{10} \mathrm{CD} 166^{+} \mathrm{GRP} 78^{-/ \mathrm{lo}}$ population is significant (Figure $5 \mathrm{~A}$ ). Consistently, with each additional antibody applied to our population (from $\mathrm{CD} 44^{+}$to $\mathrm{CD} 44^{+} \mathrm{CD} 24^{\mathrm{lo}} \mathrm{CD} 166^{+}$ and to $\mathrm{CD} 44^{+} \mathrm{CD} 24^{10} \mathrm{CD} 166^{+} \mathrm{GRP} 78^{-/ \mathrm{lo}}$ cells), we observed an increase in CFE (Figure $5 B$ ). The latter population revealed a CFE similar to that of FACS-isolated Lgr5-GFPhi cells from the transgenic reporter mouse $(P=.42, t$ test, 2 tailed, Figure $5 B)$; thus, we showed that the combination of $\mathrm{CD} 44^{+} \mathrm{CD} 24^{\mathrm{lo}} \mathrm{CD} 166^{+} \mathrm{GRP} 78^{-/ \mathrm{lo}}$ surface markers enriched for ISCs to a similar degree as the best available genetic reporter line. Although the $\mathrm{CD} 44^{+} \mathrm{CD} 24^{\mathrm{lo}} \mathrm{CD} 166^{+} \mathrm{GRP}^{+} 8^{+}$population could cover more than $82 \%$ of total Lgr5-GFPhi cells, as measured by backgating analysis (Supplementary Figure 13), the RT-PCR result revealed that it still contained a minor portion of ChgA-expressing endocrine cells (Figure $5 C)$.

We next measured the enrichment of CoSCs isolated using our surface marker combination. A similar increase in the percentage of Lgr5-GFPhi cells was observed in colon cells and reached about $17 \%$ in $\mathrm{CD} 44^{+} \mathrm{CD} 24^{10} \mathrm{CD} 166^{+} \mathrm{c}-\mathrm{Kit}^{-}$cells (Figure $5 \mathrm{D}$ ). Accordingly, the $\mathrm{CFE}$ and gene profiling of $\mathrm{CD} 44^{+} \mathrm{CD} 24^{\mathrm{lo}} \mathrm{CD} 166^{+} \mathrm{c}-\mathrm{Kit}^{-}$cells was similar to that of Lgr5-GFPhi cells (Figure $5 E$ and $F$ ).

\section{CD44 ${ }^{+}$CD24 ${ }^{\text {lo }}$ CD166+ GRP78-/lo Identifies Putative ISCs Independent of Lgr5-GFPhi Cells}

One significant limitation of using the Lgr5-GFP reporter mouse line to label stem cells is the mosaic pattern of $\mathrm{GFP}^{+}$crypts (Figure $6 A$ ). Consistently, we found that the Lgr5 expression level in the $\mathrm{CD} 44^{+} \mathrm{CD} 24^{10} \mathrm{CD} 166^{+} \mathrm{GRP} 78^{-}$population isolated from Lgr5GFPneg crypts was 50\% that of Lgr5-GFPhi cells (Figure 6C), indicating that this population included the genuine $\mathrm{Lgr} 5^{\mathrm{hi}} \mathrm{CBC}$ cells. Also, the Lgr5-GFP ${ }^{\text {neg }}$ cells had a CFE (>90\%) similar to that of Lgr5-GFPhi cells (Figure $6 D$ ), indicating that the $\mathrm{CD} 44^{+} \mathrm{CD} 24^{\mathrm{lo}} \mathrm{CD} 166^{+}$ $\mathrm{GRP}^{-/ 1 \mathrm{lo}}$ markers enabled sorting putative ISCs from Lgr5-GFPneg crypts, independent of Lgr5-GFP reporter.

Different GFP expression levels in the Lgr5-GFP ${ }^{+}$crypts (Figure $6 \mathrm{~A}$ ) were reported to faithfully reflect the endogenous Lgr5 expression levels and to distinguish $\mathrm{CBC}$ cells and progenitor cells. ${ }^{18,29}$ Derived from the $\mathrm{CD} 44^{+} \mathrm{CD} 24^{\mathrm{lo}} \mathrm{CD} 166^{+} \mathrm{GRP} 78^{-/ \mathrm{lo}}$ population, Lgr5GFPlo/med and Lgr5-GFPhi subpopulations had an average CFE of $19 \%$ and $27 \%$, respectively (Figure $6 C$ and $D$ ). In contrast, Lgr5-GFPlo/med cells within the $\mathrm{CD} 44^{+} \mathrm{CD} 24^{\text {lo }} \mathrm{CD} 166^{+} \mathrm{GRP} 78^{+}$gate barely formed colonies (data not shown). Recent studies confined the high level of Lgr5 expression to the PC zone, while Olfm4 and Ascl2 showed broader expression in both $\mathrm{CBC}$ and +4 position. ${ }^{18,30}$ Similarly, we also detected that expression levels of $\mathrm{Olfm} 4$ and $A s c 12$ in the $\mathrm{Lgr} 5-\mathrm{GFP}{ }^{\mathrm{lo} / \mathrm{med}}$ population were approximately $40 \%$ that of the Lgr5-GFPhi population, consistent with the notion that Lgr5GFPlo/med cells are most likely located at the +4 position above the CBC zone. Thus, based on the gene expression signature and CFE tests of these 2 different subpopulations, we concluded that within the Lgr5-GFP-positive crypts, not all colony-forming cells were derived from Lgr5-GFPhi cells. Some Lgr5-GFPlo/med cells located mainly above the CBCPC zone (Figure $6 A$ ) were capable of forming enteroids. 
We then asked whether Lgr5-GFPlo/med and Lgr5-GFPneg cells identified by surface markers could give rise to Lgr5-GFPhi enteroids. We showed that while the Lgr5-GFPneg cells gave rise mainly to Lgr5-GFP neg enteroids, the Lgr5-GFPlo/med cells could generate new enteroids containing Lgr5-GFPhi cells (Figure $6 E$ and $F$ ). Compared with Lgr5-GFPhi ISCderived enteroids, Lgr5-GFPlo/med ISC-derived enteroids shared similar expression levels of Lgr5, Ascl2, and other differentiated cell markers. Both groups can be maintained long-term in vitro (Supplementary Figure 14). Taken together, these results provide new evidence for putative ISCs located above the PC zone, consistent with the recently reported interconversion between ISC populations residing in distinct zones of the crypt. ${ }^{4,6,31}$ It was recently reported that $\mathrm{D} 111^{+} \mathrm{CD} 24^{\text {med }}$ cells could generate enteroids with $1 \% \mathrm{CFE}$ under high doses of Wnt ligand ${ }^{32}$; however, our CD24 ${ }^{\text {lo }}$ sorted cells could largely exclude Dl11 ${ }^{+}$cells and the corresponding CFE was much higher (20\%-30\%).

\section{The New Culture Strategy Could Be Translated to Human Intestinal Tissue}

The current barrier in translating mouse studies into human tissue has been the low efficiency of culture of human small intestinal crypts and the difficulty of long-term in vitro maintenance. We tested the culture method that we developed in mice on human small intestinal tissue. Adding CHIR99021 $(2.5 \mu \mathrm{mol} / \mathrm{L})$ and other reported factors ${ }^{33}$ during the first 2 days increased the efficiency of enterosphere formation (Figure $7 A$ and $B$ ). The enterospheres underwent extensive budding to give rise to enteroids after 4 days and could be maintained over 3 months (Figure $7 C$ ). After withdrawing Wnt3a factor, ${ }^{33}$ the major differentiated cell types could be detected in the human enteroids (Figure $7 D$ ).

We further applied our culture method to surface marker-mediated FACS-isolated single human intestinal cells. We found that $\mathrm{CD} 44^{+} \mathrm{CD} 166^{+} \mathrm{CD} 24^{\mathrm{lo}}$ cells could identify IECs expressing stem cell markers (Supplementary Figure 15). However, we also noted that adding CD166 and GRP78 did not distinguish distinctive subpopulations as observed in mouse intestinal tissue. Furthermore, we found that the level of CD24 expression varied from proximal (high) to distal (low) regions of human intestine (data not shown). Finally, our data indicated that the addition of the GSK inhibitor, instead of other reported factors, ${ }^{33}$ enhanced colony formation from single $\mathrm{CD} 44^{+} \mathrm{CD} 166^{+} \mathrm{CD} 24^{\mathrm{lo}}$ cells but that the efficiency was not more than 1\% (Supplementary Figure 15). Taken together, our proposed surface marker paradigm and culture method provide a strong foundation for continued optimization for isolation and characterization of human ISCs.

\section{Discussion}

Identification of highly purified functional ISCs is required for understanding their properties and for translational studies using human ISCs. Using transgenic reporters to isolate ISCs has several limitations. (1) The mosaic expression pattern of the reporter gene results in an inability to distinguish a truly negative population. (2) Direct application of these studies to the human system is difficult. (3) A single reporter could exclude important ISC subpopulations. Progress in other stem cell systems, particularly the hematopoietic system, which depended on the use of multiple, combinatorial cell surface markers to identify different hematopoietic stem cell subsets, is being applied to basic and clinical research. The study presented here will begin alleviating these deficiencies in the ISC field.

Our study showed that differentiated cells and progenitor cells share many reported single markers such as CD24, CD166, and EphB2 ${ }^{\text {hi }}$ with ISCs (Figures 1 and 3). ${ }^{9,12}$ Similar to the hematopoietic system, multiple cell surface marker combinations were shown to be essential for the effective exclusion of differentiated cells. We systemically tested combinations of new as well as previously reported cell surface markers by gene profiling and functional assays. We also tested a new strategy to exclude villous cells using antibody B6A6, which 
recognizes most villous cells except goblet cells (Supplementary Figure 16). The new marker GRP78 showed the ability to separate ISCs from progenitor cells when combined with markers CD44, CD24, and CD166. For human tissue, however, additional markers will be required to further exclude differentiated cells from the $\mathrm{CD} 44^{+} \mathrm{CD} 24^{\mathrm{lo}} \mathrm{CD} 166^{+}$ population. Upon completion of this work, a new anti-Lgr5 antibody recognizing overexpressed Lgr5 in cancer cell lines was reported. ${ }^{34,35}$ This antibody should solve the problem of mosaic expression patterns in the transgenic reporter line; however, whether Lgr5 $5^{\text {hi }}$ versus $\mathrm{Lgr} 5^{\mathrm{med} / \mathrm{lo}}$ can be distinguished using this antibody is unknown.

Previously reported high CFE of ISCs depended on coculturing with niche cells, which cannot be replaced by exogenous Wnt3a. ${ }^{13}$ Similarly, a recent report indicated that constitutive activation of the Wnt pathway by deletion of Apc in Lgr5-GFPhi cells still led to only a $0.6 \%$ CFE. ${ }^{36}$ Here, we showed that transient application of the GSK- $3 \beta$ inhibitor CHIR99021 instead of Wnt3a and R-Spondin promoted the survival of single ISCs during the first 2 days, suggesting that antiapoptotic pathways are activated downstream of GSK-3 $\beta$ inhibition. Moreover, compared with Y27632, the E-cadherin stabilizer Thiazovivin also supported higher CFE, and this may be due to decreasing anoikis by improved E-cadherin stabilization. This new culture protocol is also applicable to human ISCs, emphasizing its clinical relevance.

Despite being a valuable tool, overreliance on single-gene reporters may result in failure to recognize the complexity of different ISC subsets. Benefiting from the Lgr5-GFP mice, we unexpectedly found that the Lgr5-GFPlo/med cells within the Lgr5-GFP-positive crypts isolated from GRP78 $8^{-/ \mathrm{lo}}$ but not from $\mathrm{GRP} 78^{+}$of the $\mathrm{CD} 44^{+} \mathrm{CD} 24^{\mathrm{lo}} \mathrm{CD} 166^{+}$subpopulation could also efficiently form enteroids. This observation indicates that our surface markers can select enteroid-forming $\mathrm{Lgr} 5^{\mathrm{lo} / \mathrm{med}}$ cells outside the PC zone, supporting the existence of a non-Lgr5 ${ }^{\text {hi }}$ ISC population. In addition, the low CD24 expression and high CFE of these cells indicate that they are different from recently reported $\mathrm{D} 111^{+} \mathrm{CD} 24^{\text {med }}$ progenitors, which have very low CFE. ${ }^{32}$

In summary, we showed that $\mathrm{CD} 44^{+} \mathrm{CD} 24^{\mathrm{lo}} \mathrm{CD} 166^{+}$plus GRP78 ${ }^{\mathrm{lo} /}-$ or c-Kit ${ }^{-}$identifies putative ISCs and CoSCs in mice. These surface marker combinations and the clonal assay, in principle, can be applied to the human system, which will be critical for future clinical application.

\title{
Supplementary Material
}

Refer to Web version on PubMed Central for supplementary material.

\section{Acknowledgments}

The authors thank H. Clevers for providing Lgr5-GFP mice; M. Hembree, M. McClain, R. T. Ross, T. Johnson, H. Marshall, B. Lewis, D. Dukes, C. Semerad, J. Park, S. Beckham, F. Guo, and W. McDowell for technical support; A. Venkatraman, R. Sugimura, M. Zhao, and F. Tao for scientific discussion; K. Tannen for editing; and I. Schmid and the FACS facilities at University of California, Los Angeles Jonsson Comprehensive Cancer Center and AIDS Research Center for extra sorting support.

Funding This research was performed as a project of the Intestinal Stem Cell Consortium, L. Li (U01DK085507), M. H. Wong (U01DK85525), M. Martin (U01DK85535), S. T. Magness (U01DK085547: SJH/STM), and the Coordinating Center J. Niland (U01DK85532). L. Li is supported in part by Stowers Institute for Medical Research.

\section{Abbreviations used in this paper}

\author{
CBC crypt base columnar
}




$\begin{array}{ll}\text { CFE } & \text { colony-forming efficiency } \\ \text { CoSC } & \text { colonic stem cell } \\ \text { FACS } & \text { fluorescence-activated cell sorting } \\ \text { GRP } & \text { green fluorescent protein } \\ \text { IEC } & \text { intestinal epithelial cell } \\ \text { IHC } & \text { immunohistochemistry } \\ \text { ISC } & \text { intestinal stem cell } \\ \text { PC } & \text { Paneth cell } \\ \text { qRT-PCR } & \text { quantitative reverse-transcription polymerase chain reaction }\end{array}$

\section{References}

1. Barker N, van Es JH, Kuipers J, et al. Identification of stem cells in small intestine and colon by marker gene Lgr5. Nature. 2007; 449:1003-1007. [PubMed: 17934449]

2. Sangiorgi E, Capecchi MR. Bmi1 is expressed in vivo in intestinal stem cells. Nat Genet. 2008; 40:915-920. [PubMed: 18536716]

3. Montgomery RK, Carlone DL, Richmond CA, et al. Mouse telomerase reverse transcriptase (mTert) expression marks slowly cycling intestinal stem cells. Proc Natl Acad Sci U S A. 2011; 108:179184. [PubMed: 21173232]

4. Tian H, Biehs B, Warming S, et al. A reserve stem cell population in small intestine renders Lgr5positive cells dispensable. Nature. 2011; 478:255-259. [PubMed: 21927002]

5. Powell AE, Wang Y, Li Y, et al. The Pan-ErbB negative regulator Lrig1 is an intestinal stem cell marker that functions as a tumor suppressor. Cell. 2012; 149:146-158. [PubMed: 22464327]

6. Takeda N, Jain R, LeBoeuf MR, et al. Interconversion between intestinal stem cell populations in distinct niches. Science. 2011; 334:1420-1424. [PubMed: 22075725]

7. Merlos-Suarez A, Barriga FM, Jung P, et al. The intestinal stem cell signature identifies colorectal cancer stem cells and predicts disease relapse. Cell Stem Cell. 2011; 8:511-524. [PubMed: 21419747]

8. Gracz AD, Ramalingam S, Magness ST. Sox9 expression marks a subset of CD24-expressing small intestine epithelial stem cells that form organoids in vitro. Am J Physiol Gastrointest Liver Physiol. 2010; 298:G590-G600. [PubMed: 20185687]

9. Levin TG, Powell AE, Davies PS, et al. Characterization of the intestinal cancer stem cell marker CD166 in the human and mouse gastrointestinal tract. Gastroenterology. 2010; 139:2072-2082. e5. [PubMed: 20826154]

10. von Furstenberg RJ, Gulati AS, Baxi A, et al. Sorting mouse jejunal epithelial cells with CD24 yields a population with characteristics of intestinal stem cells. Am J Physiol Gastrointest Liver Physiol. 2011; 300:G409-G417. [PubMed: 21183658]

11. Sato T, Vries RG, Snippert HJ, et al. Single Lgr5 stem cells build crypt-villus structures in vitro without a mesenchymal niche. Nature. 2009; 459:262-265. [PubMed: 19329995]

12. Sato T, van Es JH, Snippert HJ, et al. Paneth cells constitute the niche for Lgr5 stem cells in intestinal crypts. Nature. 2011; 469:415-418. [PubMed: 21113151]

13. Yilmaz OH, Katajisto P, Lamming DW, et al. mTORC1 in the Paneth cell niche couples intestinal stem-cell function to calorie intake. Nature. 2012; 486:490-495. [PubMed: 22722868]

14. Rothenberg ME, Nusse Y, Kalisky T, et al. Identification of a cKit(+) colonic crypt base secretory cell that supports Lgr5(+) stem cells in mice. Gastroenterology. 2012; 142:1195-1205. [PubMed: 22333952]

15. Potten CS, Booth C, Pritchard DM. The intestinal epithelial stem cell: the mucosal governor. Int J Exp Pathol. 1997; 78:219-243. [PubMed: 9505935] 
16. He XC, Zhang J, Tong WG, et al. BMP signaling inhibits intestinal stem cell self-renewal through suppression of Wnt-beta-catenin signaling. Nat Genet. 2004; 36:1117-1121. [PubMed: 15378062]

17. Cheng H, Leblond CP. Origin, differentiation and renewal of the four main epithelial cell types in the mouse small intestine. V. Unitarian theory of the origin of the four epithelial cell types. Am J Anat. 1974; 141:537-561. [PubMed: 4440635]

18. Munoz J, Stange DE, Schepers AG, et al. The Lgr5 intestinal stem cell signature: robust expression of proposed quiescent '+4' cell markers. EMBO J. 2012; 31:3079-3091. [PubMed: 22692129]

19. Yan KS, Chia LA, Li X, et al. The intestinal stem cell markers Bmi1 and Lgr5 identify two functionally distinct populations. Proc Natl Acad Sci U S A. 2012; 109:466-471. [PubMed: 22190486]

20. Van Landeghem L, Santoro MA, Krebs AE, et al. Activation of two distinct Sox9-EGFPexpressing intestinal stem cell populations during crypt regeneration after irradiation. Am J Physiol Gastrointest Liver Physiol. 2012; 302:G1111-G1132. [PubMed: 22361729]

21. Wang F, Zou Z, Liu D, et al. Active deformation of apoptotic intestinal epithelial cells with adhesion-restricted polarity contributes to apoptotic clearance. Lab Invest. 2011; 91:462-471. [PubMed: 21042290]

22. Wang F, Wang J, Liu D, et al. Normalizing genes for real-time polymerase chain reaction in epithelial and nonepithelial cells of mouse small intestine. Anal Biochem. 2010; 399:211-217. [PubMed: 20036209]

23. Miharada K, Karlsson G, Rehn M, et al. Cripto regulates hematopoietic stem cells as a hypoxicniche-related factor through cell surface receptor GRP78. Cell Stem Cell. 2011; 9:330-344. [PubMed: 21982233]

24. Jung P, Sato T, Merlos-Suarez A, et al. Isolation and in vitro expansion of human colonic stem cells. Nat Med. 2011; 17:1225-1227. [PubMed: 21892181]

25. Ying QL, Wray J, Nichols J, et al. The ground state of embryonic stem cell self-renewal. Nature. 2008; 453:519-523. [PubMed: 18497825]

26. Perry JM, He XC, Sugimura R, et al. Cooperation between both Wnt/\{beta $\}$-catenin and PTEN/ $\mathrm{PI} 3 \mathrm{~K} /$ Akt signaling promotes primitive hematopoietic stem cell self-renewal and expansion. Genes Dev. 2011; 25:1928-1942. [PubMed: 21890648]

27. Xu Y, Zhu X, Hahm HS, et al. Revealing a core signaling regulatory mechanism for pluripotent stem cell survival and self-renewal by small molecules. Proc Natl Acad Sci U S A. 2010; 107:8129-8134. [PubMed: 20406903]

28. Stelzner M, Helmrath M, Dunn JC, et al. A nomenclature for intestinal in vitro cultures. Am J Physiol Gastrointest Liver Physiol. 2012; 302:G1359-G1363. [PubMed: 22461030]

29. Snippert HJ, van der Flier LG, Sato T, et al. Intestinal crypt homeostasis results from neutral competition between symmetrically dividing Lgr5 stem cells. Cell. 2010; 143:134-144. [PubMed: 20887898]

30. Itzkovitz S, Lyubimova A, Blat IC, et al. Single-molecule transcript counting of stem-cell markers in the mouse intestine. Nat Cell Biol. 2012; 14:106-114. [PubMed: 22119784]

31. Li L, Clevers H. Coexistence of quiescent and active adult stem cells in mammals. Science. 2010; 327:542-545. [PubMed: 20110496]

32. van Es JH, Sato T, van de Wetering M, et al. Dll1(+) secretory progenitor cells revert to stem cells upon crypt damage. Nat Cell Biol. 2012; 14:1099-1104. [PubMed: 23000963]

33. Sato T, Stange DE, Ferrante M, et al. Long-term expansion of epithelial organoids from human colon, adenoma, adenocarcinoma, and Barrett's epithelium. Gastroenterology. 2011; 141:17621772. [PubMed: 21889923]

34. Kemper K, Prasetyanti PR, De Lau W, et al. Monoclonal antibodies against lgr5 identify human colorectal cancer stem cells. Stem Cells. 2012; 30:2378-2386. [PubMed: 22969042]

35. Kobayashi S, Yamada-Okabe H, Suzuki M, et al. LGR5-positive colon cancer stem cells interconvert with drug-resistant LGR5-negative cells and are capable of tumor reconstitution. Stem Cells. 2012; 30:2631-2644. [PubMed: 23081779]

36. Schepers AG, Snippert HJ, Stange DE, et al. Lineage tracing reveals Lgr5+ stem cell activity in mouse intestinal adenomas. Science. 2012; 337:730-735. [PubMed: 22855427] 

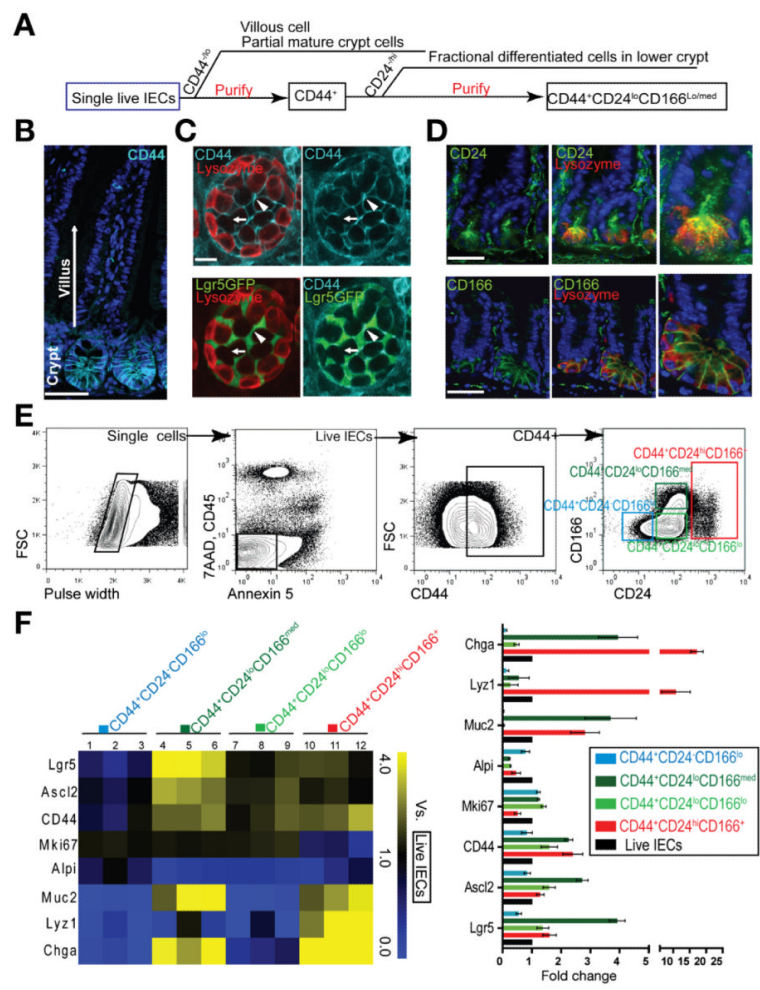

Figure 1.

Combination of CD44, CD24, and CD166 preliminarily excludes small intestinal differentiated cells. $(A)$ Experimental scheme of excluding villus and crypt differentiated cells. (B) Immunohistochemistry (IHC) staining shows gradient expression of CD44 in crypts but not in villi. (C) Confocal cross section of crypt bottom, showing strong staining of CD44 (bright blue) in the junctions of Lgr5-GFPhi stem cells (green, arrowheads) and weak staining between PCs (red, arrows). (D) IHC staining of CD24 and CD166 (green) shows higher expression at the crypt base. $(E)$ FACS strategy for sequentially gating single cells, live IECs, CD44 ${ }^{+}$cells, and cells with different CD24 and CD166 expression. $(F)$ qRT-PCR analysis showing the stem cell and differentiation marker expression in 4 subpopulations gated from $\mathrm{CD}_{4}{ }^{+}$cells versus total live IECs by heat map (left) and column chart (right). Data are presented as mean \pm SEM $(\mathrm{n}=3)$. Scale bars $=50 \mu \mathrm{m}(B$ and $D) ; 20 \mu \mathrm{m}(C)$. 
A

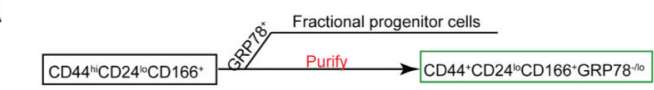

B

C
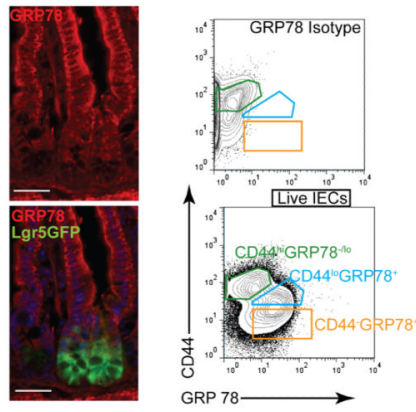

D

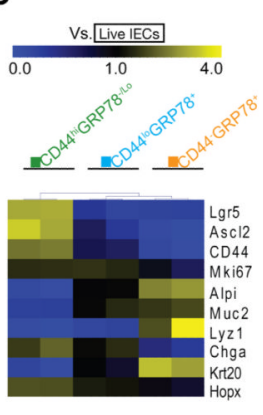

E

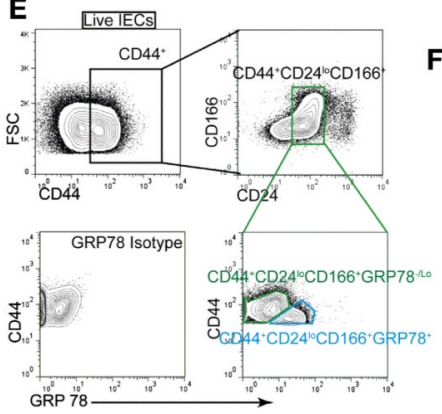

F

- CD $44^{\circ} \mathrm{CD} 24^{\mathrm{b}} \mathrm{CD} 166^{+} \mathrm{GRP} 78^{-\mathrm{ho}}$

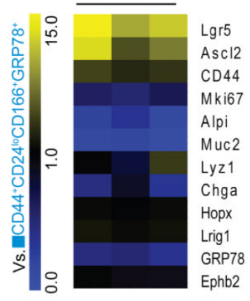

Figure 2.

GRP78 excludes progenitors in the $\mathrm{CD} 44^{+} \mathrm{CD} 24{ }^{\mathrm{lo}} \mathrm{CD} 166^{+}$population. $(A)$ Experimental scheme of excluding progenitor and differentiated cells from CD44, CD24, and CD166 cells using GRP78 ${ }^{+}$. (B) IHC staining shows high expression of GRP78 (red) in the villi and upper crypt but low expression in the stem cell zone at the crypt base. (C) Single live IECs divided into 3 subgates of CD $44^{\text {hi }} \mathrm{GRP} 78^{-/ \mathrm{lo}}$, CD $44^{\text {lo }} \mathrm{GRP} 78^{+}$, and CD $44^{-} \mathrm{GRP} 78^{+}$. (D) Heat map of qRT-PCR results shows the gene expression relative to single live IECs in 3 subgates $(C)(\mathrm{n}=2)$. $(E)$ Two subgates of $\mathrm{CD} 44^{+} \mathrm{CD} 24^{\mathrm{lo}} \mathrm{CD} 166^{+} \mathrm{GRP} 78^{-/ \mathrm{lo}}$ and $\mathrm{CD} 44^{+} \mathrm{CD} 24^{10} \mathrm{CD} 166^{+} \mathrm{GRP} 78^{+}$. $(F)$ Heat map of qRT-PCR results shows the gene expression profiling in $\mathrm{CD} 44^{+} \mathrm{CD} 24^{\mathrm{lo}} \mathrm{CD} 166^{+} \mathrm{GRP} 78^{-/ 10}$ cells relative to the $\mathrm{CD} 44^{+} \mathrm{CD} 24^{\mathrm{lo}} \mathrm{CD} 166^{+} \mathrm{GRP} 78^{+}$population $(\mathrm{n}=3)$. Scale bars $=50 \mu \mathrm{m}(B)$. 
A

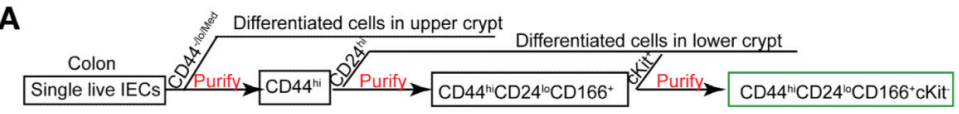

B
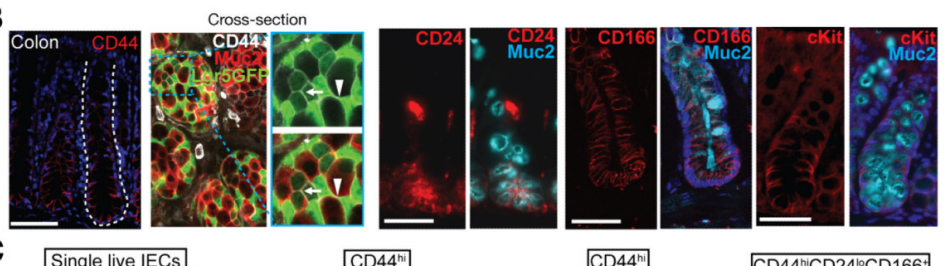

C
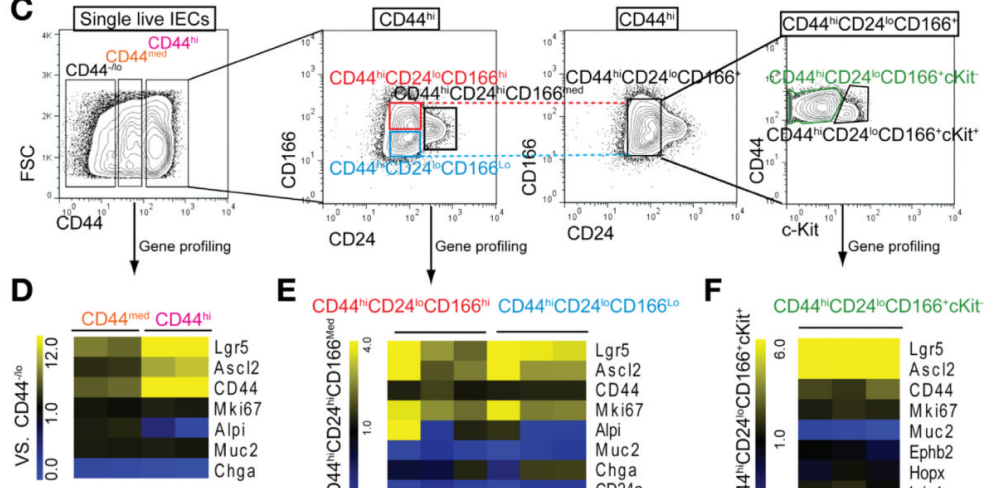

E

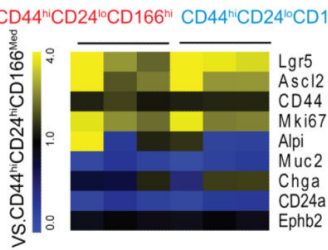

$\mathbf{F}$

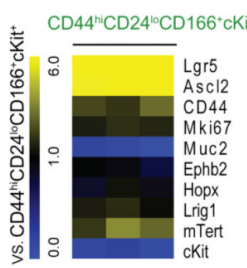

Figure 3.

CD44, CD24, CD166, c-Kit combination identifies CoSCs. $(A)$ Experimental scheme of gradually purifying colonic ISCs. $(B)$ IHC staining shows expression pattern of CD44, CD24, CD166, and c-Kit in colon. The cross section shows the expression of CD44 (white) in $\mathrm{Muc}^{+}$(red) cells adjacent to Lgr5-GFPhi (green) cells (arrowheads) and in the conjunction of Lgr5-GFPlo cells (arrows). (C) Sequential FACS plots and gates as indicated. (D) qRT-PCR results show gene expression in the $\mathrm{CD} 44^{\text {med }}$ and CD44 ${ }^{\text {hi }}$ cells versus CD44 ${ }^{\mathrm{lo}}-$ cells $(\mathrm{n}=2)$. $(E)$ Gene expression in $\mathrm{CD} 44^{\text {hi }} \mathrm{CD} 24^{\mathrm{lo}} \mathrm{CD} 166^{\mathrm{lo}}$ and $\mathrm{CD} 44{ }^{\text {hi }} \mathrm{CD} 24^{\mathrm{lo}} \mathrm{CD} 166^{\text {hi }}$ populations relative to the $\mathrm{CD} 44^{\text {hi }} \mathrm{CD} 24{ }^{\text {hi }} \mathrm{CD} 166^{\text {med }}$ population $(E)$ and further separation with c-Kit $(F)(\mathrm{n}=3)$. Scale bars $=50 \mu \mathrm{m}(B) ; 10 \mu \mathrm{m}(B$, magnification). 

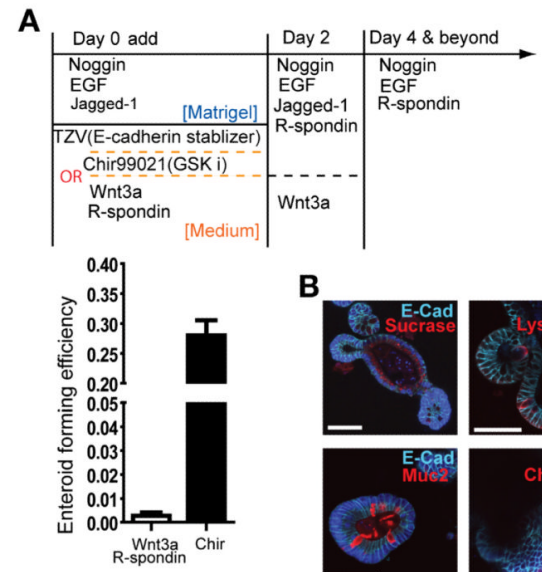

B
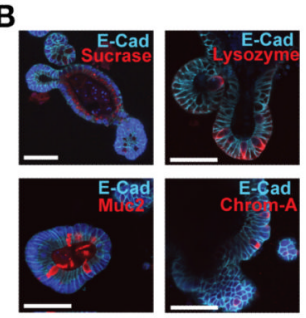

C
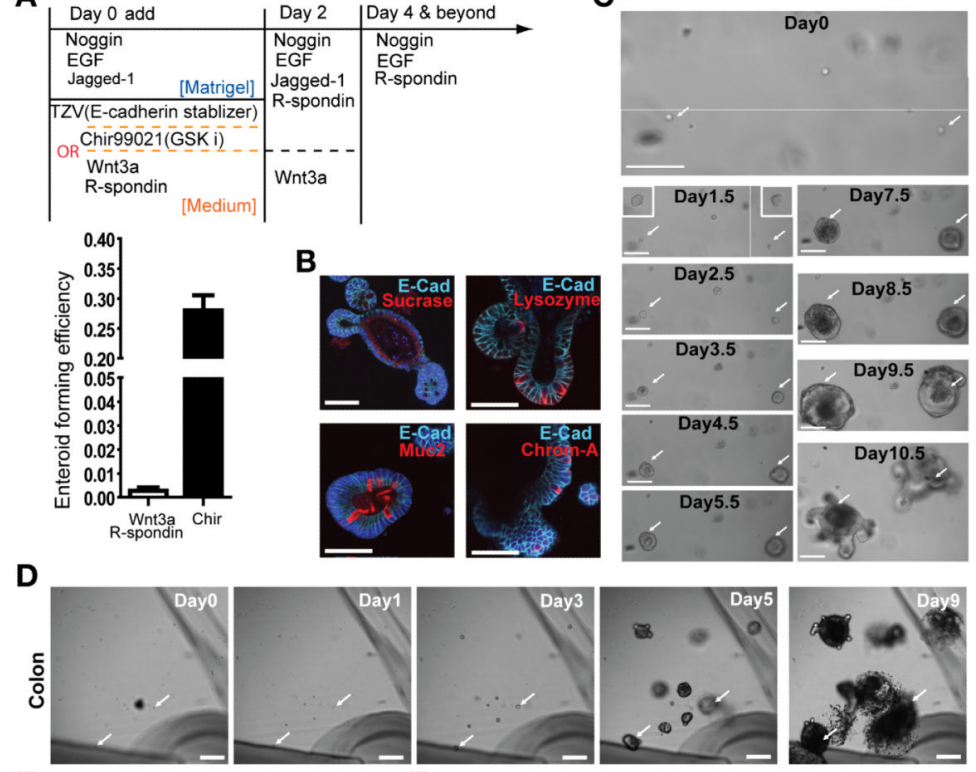

E
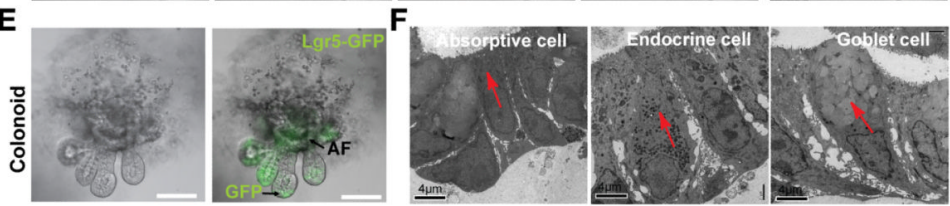

Figure 4.

Small molecules enable robust culturing of bona fide single ISCs or CoSCs. $(A)$ Strategies to culture single Lgr5-GFPhi cells and comparison of Wnt3a and CHIR99021 have an impact on CFE. Data are presented as mean $\pm \operatorname{SEM}(P=.0004, t$ test, $\mathrm{n}=3)$. (B) IHC staining shows the differentiated cell type in the enteroid derived from single ISCs. ( $C$ ) Representative images recording the process of single Lgr5-GFPhi cell-forming enteroids. $(D)$ A growth process from a single Lgr5-GFPhi CoSC into colonoid. (E) An open colonoid structure derived from a single Lgr5-GFPhi CSC. AF, autofluorescence. $(F)$ Colonoids containing differentiated cell types identified by electron microscopic analysis. Scale bars $=$ $50 \mu \mathrm{m}(B) ; 100 \mu \mathrm{m}(C, D, E) ; 4 \mu \mathrm{m}(F)$. 


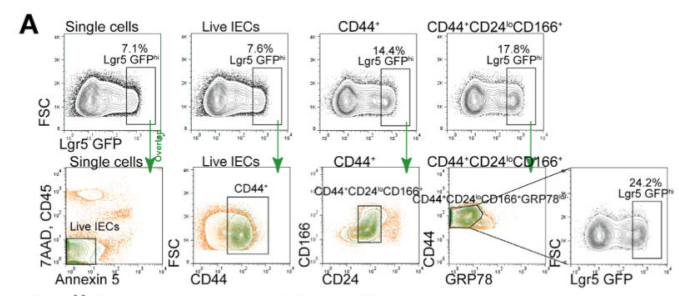

B

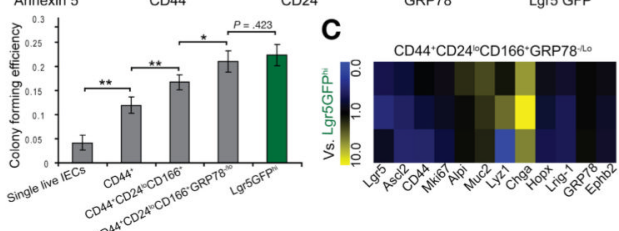

D Single cells

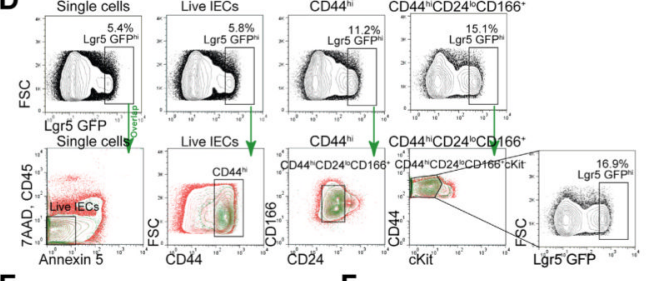

E

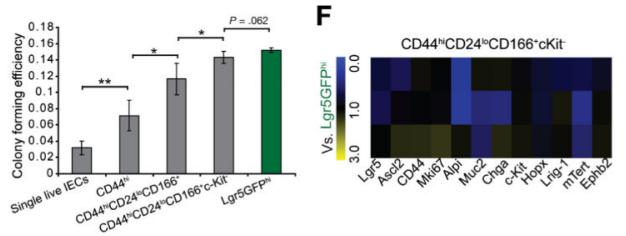

Figure 5.

The surface marker combination identifies the ISC population with CFE comparable to that of Lgr5-GFPhi cells. $(A)$ Lgr5-GFPhi cells in parent gates were largely confined in daughter gates, showing the gradual selection by surface marker combination. $(B)$ CFE analysis of different subpopulations. Data are presented as mean $\pm \mathrm{SEM},(* P<.05, * * P<.01, \mathrm{n}=4, t$ test). (C) The gene profiling of $\mathrm{CD} 44^{+} \mathrm{CD} 24^{\text {lo }} \mathrm{CD} 166^{+} \mathrm{GRP} 78^{-/ l o}$ cells, taking Lgr5-GFPhi ISCs as control $(\mathrm{n}=3)$. ( $D)$ Colonic Lgr5-GFPhi cells in parent gates were largely confined in daughter gates, showing the gradual purification by surface marker combination. $(E) \mathrm{CFE}$ analysis of series of gates. Data are presented as mean $\pm \mathrm{SEM}(* P<.05, * * P<.01, \mathrm{n}=4, t$ test). $(F)$ The gene profiling of $\mathrm{CD} 44^{\mathrm{hi}} \mathrm{CD} 24^{\mathrm{lo}} \mathrm{CD} 166^{+} \mathrm{cKit}^{-}$cells, taking $\mathrm{Lgr} 5-\mathrm{GFP}$ hi $\mathrm{CoSCs}$ as control $(n=3)$. 
A
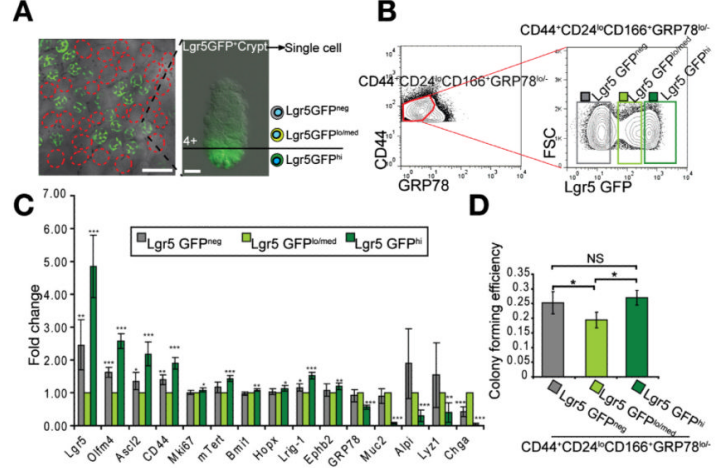

。
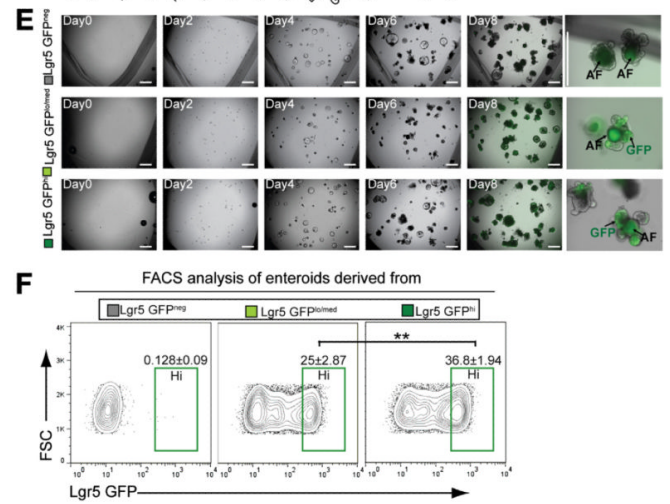

Figure 6.

$\mathrm{CD} 44^{+} \mathrm{CD} 24^{\text {lo }} \mathrm{CD} 166^{+}$GRP78 $8^{-/ 10}$ identifies ISCs independent of Lgr5-GFPhi cells. $(A)$ The mosaic distribution of Lgr5-GFP ${ }^{+}$crypt in jejunum. Gradient GFP expression in Lgr5-GFP ${ }^{+}$ crypt. $(B)$ Lgr5-GFPneg, Lgr5-GFPlo/med, and Lgr5-GFPhi gates in the $\mathrm{CD} 44^{+} \mathrm{CD} 24^{\mathrm{lo}} \mathrm{CD} 166^{+} \mathrm{GRP} 78^{-/ 1 \mathrm{lo}}$ population. (C) qRT-PCR results show the gene expression of Lgr5-GFPneg and Lgr5-GFPhi cells relative to Lgr5-GFPlo/med cells from the $\mathrm{CD} 44^{+} \mathrm{CD} 24^{\mathrm{lo}} \mathrm{CD} 166^{+} \mathrm{GRP} 78^{-/ \mathrm{lo}}$ population. Data are presented as mean $\pm \mathrm{SEM}\left(\mathrm{n}=4,{ }^{*} P\right.$ $<.05, * * P<.01, * * * P<.001) .(D)$ CFE analysis of the Lgr5-GFP ${ }^{\text {neg }}, \mathrm{Lgr} 5-\mathrm{GFP}$ lo/med , and Lgr5-GFPhi cells in the gates of $B$. Data are represented as mean \pm SEM $(* P<.05, \mathrm{n}=3, t$ test). (E) A growth process of single cells sorted from Lgr5-GFPneg, Lgr5-GFPlo/med, and Lgr5-GFPhi gates in $B$, showing that Lgr5-GFPlo/med cells can generate Lgr5-GFPh enteroid. $(F)$ FACS analysis of enteroids derived from single Lgr5-GFP ${ }^{\text {neg }}$, Lgr5-GFPlo/med, and Lgr5-GFPhi cells, showing that single Lgr5-GFPlo/med cells can generate enteroids containing Lgr5-GFPhi cells as single Lgr5-GFPhi cells did. Data are presented as mean \pm $\operatorname{SEM}(\mathrm{n}=3, * * P<.01)$. 

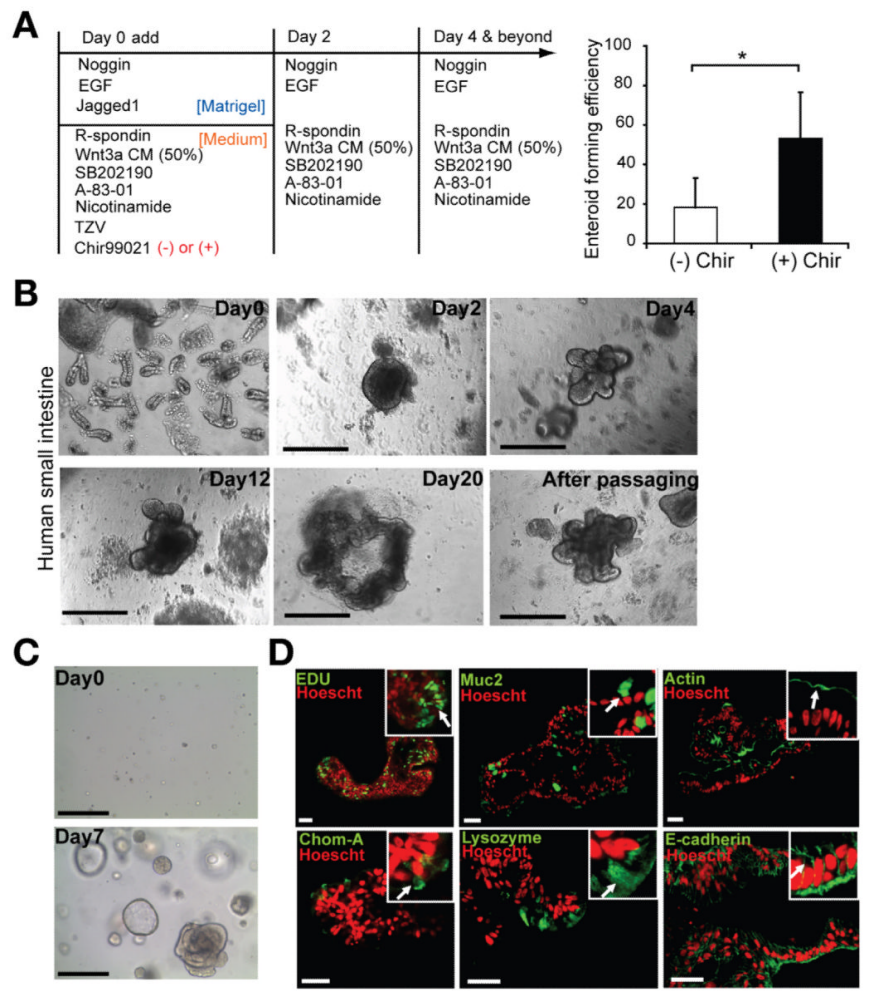

Figure 7.

The new culture strategy enables highly efficient human crypt culture and maintenance. $(A)$ Crypt culture strategy. CHIR99021 significantly increased the efficiency of culturing human small intestinal crypts. Data are presented as mean \pm SEM ( $\mathrm{n}=6, * P .011, t$ test). (B)

Representative growth process of human small intestinal crypt culture with addition of a single dose of GSK inhibitor CHIR99021 and other factors. ${ }^{33}$ (C) Human enteroid can be passaged up to 10 times over a 3-month period, as shown by their growth after passaging from day 0 to day 7. $(D)$ IHC staining show the cellular proliferation and differentiated cell types in cultured enteroid. Positive staining is indicated by the arrow in the inset. Scale bars $=200 \mu \mathrm{m}(B$ and $C) ; 50 \mu \mathrm{m}(D)$. 